\title{
Ambivalent sexism and sexual objectification of women as predictors of rape myth acceptance among male college students in Greater Jakarta
}

\author{
Elizabeth Kristi Poerwandari ${ }^{1}$ (D) $\cdot$ Carina Putri Utami ${ }^{1} \cdot$ Indira Primasari $^{1}$ (D) \\ Published online: 14 November 2019 \\ (C) The Author(s) 2019
}

\begin{abstract}
Sexual violence against women, particularly in the form of rape, is a serious issue that must be addressed in Indonesia. However, victims of sexual violence are not enveloped by a supportive atmosphere due to the pervasive acceptance of rape myths in society. This study examined the role of ambivalent sexism and sexual objectification of women in predicting the acceptance of rape myths among male college students in Greater Jakarta, Indonesia. A sample of 275 male college students completed the Illinois Rape Myth Acceptance Scale-Short Form, Ambivalent Sexism Inventory, and Women Are Sexual Objects subscale from the Attitude Toward Dating and Relationship Measure Revised. The results of multiple regression analysis showed that ambivalent sexism and sexual objectification of women significantly predicted rape myth acceptance, with sexual objectification of women tends to have more contribution. This finding explains that to develop and conduct prevention and treatment, both variables need to be addressed, with more attention given to the sexual objectification of women.
\end{abstract}

Keywords Rape myth acceptance $\cdot$ Ambivalent sexism $\cdot$ Sexual objectification $\cdot$ Male students $\cdot$ Indonesia

\section{Background}

Sexual violence against women is a severe problem in Indonesia. According to the Yearly review (Catatan tahunan or Catahu) of Komnas Perempuan (the National Commission on Violence Against Women, a state institution set up by presidential decree in 1998 that combines data from various service institutions, police departments and courts), there have been increases in sexual assault cases both in the personal sphere (whereby the perpetrator is related to the victim by blood, marriage, or intimate relations) and at the community level (cases in which there is no close relationship between the victim and the perpetrator) (Komnas Perempuan 2015, 2016,

Elizabeth Kristi Poerwandari

elizabeth.kristi@ui.ac.id

Carina Putri Utami

carina.putri1@gmail.com

Indira Primasari

indiraprimasari@ui.ac.id

1 Faculty of Psychology, Universitas Indonesia, Depok Campus, Depok, West Java 16424, Indonesia
2017, 2018). The most recent data from 2018 showed that sexual assaults comprised $31 \%$ of the total violence reported within family or other close personal relationships (husband and wife, couples living together, or man and woman dating). In addition, sexual assaults comprised $76 \%$ the 3528 cases of violence against women recorded as having occurred in the public and community domains (Komnas Perempuan 2018).

Some case illustrations can provide an overview of the seriousness of this problem in the country:

$\mathrm{BN}$ is a woman who was a victim of sexual harassment committed by the school principal where she worked. To save evidence, BN kept a record of her conversation with the school principal on her cellphone. This recording was disseminated by BN's co-workers, that the principal reported her to the police as conducting a disrespectful or abusive act in front of the public under the Law No. 11 of 2008 concerning Information and Electronic Transactions. She was sentenced guilty by the court. (Komnas Perempuan 2018, p. 43).

Deli Serdang District Court in North Sumatra released someone who was reported as committed rape following the court decision that the report was unproven. The victim has died that she cannot be questioned anymore. She killed herself by drinking poison after the incident because her confession was not trusted by her surrounding environment. (Komnas Perempuan 2018, p. 42). 
For years, Indonesian women's groups and other members of civil society have been urging the ratification of the Law on the Elimination of Sexual Violence, which has received challenges from many parties for various reasons, including that the draft of the law was perceived as promoting values that are not in line with prevailing religious teachings or national culture.

As indicated by the above examples, despite the high prevalence of rape and other forms of sexual violence in Indonesia, the community at large has not created a supportive atmosphere for victims. Rather, certain sociocultural conditions contribute to an atmosphere of tolerance for sexual violence, such that victims are negatively labelled as 'a disgrace to the family' and are often targets of blame for the assaults. Responsibility is attributed to victims based on factors such as the clothing they were wearing, their level of consciousness at the time of the assault (whether or not they were under the influence of alcohol), or whether they were alone or accompanied by others when the sexual violence occurred.

The widespread nature of victim-blaming demonstrates an acceptance of myths or misperceptions about rape, such as when a woman's clothing is regarded as a cause. Such beliefs are misguided because women can be targeted for rape even while wearing modest clothing, as was the case in an assault in the South Jakarta region that was perpetrated by a public transport driver against an employee who was wearing a hijab (Syarif and Purnama 2015). Such examples show how rape myths are often not reality-based, and are frequently even contradictory to actual situations.

\section{The Underreporting of Rape Cases}

Data demonstrates that cases of sexual violence are underreported not only in Indonesia, but also in other parts of the world. When sexual assaults are reported, they are under-prosecuted, and when prosecuted, they are under-convicted. Fitzgerald (2006) analysed data on cases of sexual violence recorded in New South Wales, Australia and found that from cases that had been reported, less than $20 \%$ of them were proceeded to the court, with a low of conviction rate. Many barriers hinder the ability of women victims to disclose or report sexual assaults. They often experience confusion, guilt, shock, or shame, or they fear retaliation from the perpetrator and worry if their reports will be believed. The tendency to blame victims might make it difficult for women to recognise or admit that they have experienced sexual violence, and they might even blame themselves for what has been done. In addition to the above, related legal processes bring further challenges. Pursuing justice is difficult, stressful, time-consuming and expensive, with a risk that the woman victim is blamed (Commonwealth of Australia 2017).

Allen (2007) conducted a study on the underreporting of rape in the United States (US) in which it was revealed that according to US Department of Justice data for the period of 1994-1995, only an estimated one-third of rape victims reported their cases to police. One reason cited for the low reporting rate is that rape victims feared incurring consequences such as the loss of privacy as well as recriminations and reprisals. Prochuk's (2018) investigation of sexual violence cases in Canada cited that very few sexual assaults cases (only about 5\%) there are reported to the police and only approximately $11 \%$ of reported cases lead to a conviction. Barriers to disclosure include the risk of being blamed or disbelieved, as well as the drain of time, material resources and energy involved in reporting. The emotional and physical burdens that are incurred may bring unbearable consequences for women who are already struggling for their daily survival. Palermo et al. (2014) reporting on demographic and health survey data concerning gender-based violence impacting 284,281 women in 24 developing countries collected between 2004 and 2011. They found that only $7 \%$ of the victims had reported their assaults to formal authorities such as local authorities or the police. There was regional variation in reporting rates; for example, only $2 \%$ of women in India and East Asia had reported their assaults compared with $14 \%$ of women in Latin America and the Caribbean (Palermo et al. 2014).

\section{Rape Myths and their Acceptance}

The term 'rape myths' began to be more widely discussed after Brownmiller (1975) shared her insights on society's misled beliefs about sexual violence. Similarly, Estrich (1976) observed how people considered some rapes as more 'real' than others. Burt (1980) later developed a scaledquestionnaire on the acceptance of rape myths (Smith and Skinner 2017, p. 2).

A community's acceptance of rape myths has multiple negative repercussions, most notable of which are the denial of rape and the assumption that rape is not a severe issue due to the shift of blame from the perpetrator to the victim (Lonsway and Fitzgerald 1994). Lonsway and Fitzgerald (1994) refined the theoretical basis of the term 'rape myth' by differentiating it from stereotypes. Rape myths not only encompass stereotypical attitudes and assumptions, but also have a cultural function to maintain the status quo. According to Gerger et al. 2007), the term 'rape myths' refers to descriptive or prescriptive beliefs about rape that serve to deny, downplay or justify sexual violence that men commit against women. Further, rape myth acceptance increases men's tendency to commit rape because it serves as a justification for sexual violence (Bohner et al. 2005) and leads to decrease reports of such incidents (Bohner et al. 2005; Frese et al. 2004).

Studies about sexual violence and rape myths acceptance have been conducted in different cultures worldwide. Research from Bohner et al. (2009) examined the cognitive, affective and behavioural effects of rape myth acceptance. they found that it would affect people's perception of the 
seriousness of the report regarding sexual violence. Those who are hight in rape myth acceptance tend to blame the victims more, are less convinced that the victims are truly traumatized, and do not see the perpetrators as the main agents of sexual violence (Bohner, Eyssel, Pina, Siebler, and Viki 2009). Martinez et al. (2018) examined sexual assault perpetrators and rape myths among college students in Greece, and found that men expressed more tolerance of sexual harassment, were more likely to accept rape myths, and some even admitted that they might sexually assault someone under some circumstances. Fraternity men were overrepresented among sexual assault perpetrators and sorority women were at increased risk for victimisation of sexual assault.

Barn and Powers (2018) contributed to the understanding of the phenomena of rape and victim blaming with a study using data from 693 students in India and the United Kingdom. Their findings suggest that participants in India tended to endorse rape myths more than students in the UK. Barn and Powers (2018) also recognised that different myths were prevalent in the two country contexts, such that Indian students were more likely to endorse the myth of 'monster rapists', whereas British students adhered to the idea of the 'promiscuous female victim'. They argued that both types of myths are dangerous and risk normalising such perceptions in society.

Meanwhile, Nilsson (2018) examined narratives of rape in Swedish newspapers and pointed out the perpetuation of myths and stereotypes with diverse narratives, such as 'celebrity rape' or 'the lonely pervert rape', which obscure the influence of patriarchal structures by questioning the existence of the incidents, or 'monstering' the perpetrators. Nilsson (2018) proposed that attention to patriarchal dynamics might be diverted by focusing attention on other structural problems.

The negative influence of rape myth acceptance also affects elements of legal institutions. Page (2008) showed that rape myths influence interactions between law enforcement officers and rape victims, whereby police tend not to believe victims whose characteristics are inconsistent with their stereotypes (for instance, if the victim is not a virgin or has had a relationship with the suspect). Krahe et al. (2008) study of undergraduate law students who had practical experience through internships found that participants who tended to accept rape myths were less likely to conclude that rape was the responsibility of the offender and more likely to blame the victims and/or recommend shorter sentences for the perpetrators.

Barn and Kumari (2015) investigated court judgements and conducted interviews with high court judges in India and described the infusion of rape mythology into the court process during rape trials. Similarly, Smith and Skinner (2017) observed court proceedings of rape and other sexual assault trials and found that defence attorneys routinely employed rape myths, such as by focusing on inconsistencies in witness testimonies and promoting a dichotomy of wholly truthful vs. untruthful witnesses. They proposed that courts and juries conceptualise 'rational' behaviour as the 'normal' way to act, and women who are deemed as not acting rationally are not considered to be credible. However, Smith and Skinner (2017) also identified resistance to rape myths in judicial directions or prosecutors' comments.

\section{Ambivalent Sexism}

In the first published empirical study on rape myth acceptance, Burt's research (1980) found that among attitude, personality, experience and background, the former was the strongest predicting variable. The attitude variables in Burt's study included 1) sex-role stereotyping, or the perception of the appropriateness of female and male roles; 2) adversarial sexual beliefs, or the expectation that sexual relations are exploitative at their core and rape is the most extreme form of such exploitation and 3) acceptance of interpersonal violence, or the perception that forcing is a legitimate measure to gain obedience in a relationship (Burt 1980).

In addition to the variables discussed in Burt's (1980) study, sexism has an important connection to rape myth acceptance (Aosved and Long 2006; Lonsway and Fitzgerald 1994). According to Glick and Fiske (1996), sexism is comprised of two dimensions, namely hostile sexism, which embodies actively negative attitudes toward women and benevolent sexism, whereby a person subjectively deems their sexist attitudes as positive. This two-pronged construct is called ambivalent sexism due to the two evaluatively contradicting aspects (Glick and Fiske 1996). Ramos et al. (2016) demonstrated that both benevolent and hostile sexist messages communicate that women are and should be less competent than men.

Chapleau et al. (2007) identified a positive correlation between hostile sexism and rape myth acceptance, and findings from Suarez and Gadalla's (2010) meta-analysis confirmed the existence of a strong positive association between rape myth acceptance and sexual aggression as well as hostile sexism and/or aggressive behaviour toward women. Renzetti et al. (2015) study examined the moderating effects of ambivalent sexism (both hostile and benevolent sexism) on the relationship between alcohol use and intimate partner violence perpetration among a community-based sample of 255 men, and their findings indicate that greater alcohol consumption and higher levels of hostile sexism lead to an increased prevalence of intimate partner violence. Erdem and Sahin's (2017) research identified a significant correlation between participants' attitudes toward dating violence and ambivalent sexism among a sample of 1171 undergraduates.

Lila et al. (2013) conducted an important study in which they examined the roles of ambivalent sexism and empathy in attitudes toward violence against women among a sample of 
404 male police officers. Their findings indicated that participants with lower levels of benevolent sexism tended to prefer unconditional law enforcement, whereas the opposite trend characterised those with higher levels of benevolent sexism. As such, officers' attitudes regarding whether or not to press charges or not against the offender depended on the victims' willingness to do so. Those with a general preference for unconditional law enforcement were also found to exhibit higher degrees of empathy and lower levels of hostile sexism (Lila et al. 2013). Their main finding was that sexist attitudes and low levels of empathy negatively influence law enforcement attitudes toward pursuing legal justice against sexual offenders.

\section{Sexual Objectification}

Sexual objectification is another variable that influences rape myth acceptance. Objectification theory posits that women experience sexual objectification when they are treated as body parts or compilations of body parts that are valued based on their benefits for others (Fredrickson and Roberts 1997). Bartky (1990) explained that sexual objectification of women occurs when individuals separate parts or bodily functions from the whole person, thus degrading the female body's sexual parts as status symbols or mere instruments that are perceived to represent women as a whole.

Nussbaum (1995, p. 257) defined the sexual objectification of women as embodying their 'dehumanisation' as things, objects, or commodities. She identified several dimensions of this phenomenon, including 'instrumentality', whereby women are treated as tools by those who objectify them, and the denial of autonomy, such that women are treated as objects lacking in self-determination. Similarly, 'inertness' refers to women being treated as objects lacking in agency, whereas 'fungibility' points to the treatment of women as interchangeable objects. Additional elements of objectification include violability, ownership and denial of subjectivity. Women are treated as objects lacking in boundary-integrity that are owned by others, can be bought or sold and whose experiences and feelings need not be taken into account. In this manner, sexuality and sexual relations are engendered by asymmetrical power structures.

Sexual objectification has been described as a precursor to sexual violence that has important consequences for how people view victims of sexual assault (Loughnan et al. 2013; Stoltenberg 2000). When somebody sexually objectifies another person, he or she assumes that the other person is an object. The process is based on a person's perception that the objectified party is less than the perceiving subject (dehumanised) and has less complex thoughts (dementalised). Engaging in objectification ultimately affects the beholder's perception of moral treatment, i.e. the extent to which someone is deemed worthy of fair treatment and should not be harmed (Loughnan et al. 2013), which has important implications for rape victims. The sexual objectification of rape victims results in a lack of moral concern for them, which in turn influences perceptions of moral treatment toward rape victims. Based on this concept, the probability of rape myth acceptance by individuals who sexually objectify women will be higher because the victims are perceived to deserve the sexual violence that they endure.

Research is lacking on the role of ambivalent sexism and sexual objectification in predicting rape myth acceptance by male college students in Indonesia. Male college students were chosen for this study because men have consistently been found to have higher rates of rape myth acceptance compared with women (Fonow et al. 1992; Johnson et al. 1997; Lonsway and Fitzgerald 1994; Martinezetal. 2018; Suarez and Gadalla 2010; Szymanski et al. 1993). Malamuth's (1981) study of male college students found a relationship between rape myth acceptance and the probability of committing rape, such that around $35 \%$ of respondents indicated that they might commit rape if there was a guarantee that they would not be apprehended and punished. Similarly, Martinezetal. (2018) identified significant positive correlations between men college students' selfreported tolerance for sexual harassment, adversarial sexual beliefs, rape myth acceptance and the likelihood to conduct a sexual offence.

\section{About this Study}

Previous studies have shown that hostile sexism plays a greater role in sexual objectification and rape myths than the other variables described above. However, this study examined both hostile sexism and ambivalent sexism, which includes benevolent sexism. Although benevolent sexism refers to an attitude that is subjectively perceived as positive by the beholder, Ramos et al.'s (2016) research demonstrated that similar to those exhibiting hostile sexism, those with attitudes of benevolent sexism perceived women as being less competent than men. Lila et al. (2013) found that police officers with higher levels of benevolent sexism prefer to depend on the willingness of the victim when determining whether or not to press charges or not against the offender. This finding suggests the possibility that although police with greater attitudes of benevolent sexism tend to consider women's contribution to the pursuit of justice or at least attempt to protect women, their attitudes are nonetheless influenced by an underlying perception of men's superiority over women. Another possibility is that an officer harbouring benevolently sexist views might perceive sexual violence as an illegal act; however, it should not be categorised as being very severe. It is possible that in the minds of such officers, although a woman has experienced sexual violence, her acknowledged weakness requires her to continue her relations with the perpetrator or she may not want to bring the case to the law for other reasons.

Taking all of the above into consideration, in this study, we aimed to examine the roles of ambivalent sexism and sexual 
objectification of women in predicting rape myth acceptance. More specifically, this study investigated which of the two variables would be the strongest predictor of rape myth acceptance. The hypothesis tested in this study is that ambivalent sexism and sexual objectification significantly predict rape myth acceptance. In a more practical sense, this study aims to provide a theoretical basis for the application of intervention programmes devoted to raising awareness about rape myths. It is hoped that by understanding the roles of ambivalent sexism and the sexual objectification of women in predicting rape myth acceptance, educators can structure the content of intervention programmes to raise awareness of rape myths among the community at large.

\section{Methods}

The participants were 275 male, 17- to 26-year-old undergraduate students attending public or private universities in the Greater Jakarta area (Jakarta and its surrounding regions of Bogor, Depok, Tangerang and Bekasi) also known as Jabodetabek. Male participants were chosen because men are the gender group who are most often perpetrators of rape (Payne etal. 1999). Among the respondents, $48.7 \%(N=134)$ were $17-$ 20 years old and $51.3 \%(N=141)$ were $21-26$ years old, the majority $(83.6 \%, N=230)$ were Muslim and $\operatorname{most}(91.3 \%, N=$ 241) were heterosexual.

An accidental sampling technique was used whereby the respondents were the most easily recruited members of the targeted population. The recruitment method entailed disseminating details about the study along with a link to the questionnaire through the research team's private accounts (LINE) and social media accounts (Twitter, Facebook, etc.), which could be accessed by students.

This study utilised three measures: 1) the Illinois Rape Myth Acceptance-Short Form (IRMAS-SF) to measure rape myth acceptance; 2) the Ambivalent Sexism Inventory (ASI) to measure ambivalent sexism and 3) the 'Women Are Sexual Objects' subscale from the Attitude Toward Dating and Relationship Measure Revised to measure sexual objectification of women. The IRMAS-SF is the shorter version of the Illinois Rape Myth Acceptance Scale (IRMAS) developed by Payne et al. (1999), which was adapted for Bahasa Indonesian by Yolandasari (2013). This instrument consists of 20 items and has six answer options ranging from 'strongly disagree' to 'strongly agree'.

The ASI was developed by Glick and Fiske (1996). In this measure, sexism is perceived as a multidimensional construct consisting of the two subscales of hostile sexism (HS) and benevolent sexism (BS). The measure comprises 22 items with 11 items on each subscale. Like the IRMAS SF, each item is measured on a Likert-scale with six answer options ranging from 'strongly disagree' to 'strongly agree'. Developed by Ward (2002), the 'Women Are Sexual Objects' subscale of the Attitude Toward Dating and
Relationship Measure Revised contains eight Likert-scale items with six answer options ranging from 'strongly disagree' to 'strongly agree'.

The research team created adaptions of the ASI and the 'Women Are Sexual Objects' subscale, the first step of which was to translate every item on both measures. Subsequently, the translated items were reviewed by five supervisors and other experts. The research team then translated the non-reversed items. Six items were modified from reversed to non-reversed, and the translations were then reviewed once more by the experts. Finally, the translated items were back-translated from Indonesian to English by students at the Faculty of Psychology Universitas Indonesia with good English language writing abilities (paper-based TOEFL scores above 600). After the instruments were adapted, the research team conducted a trial run to measure their reliability and validity. The measures were first given to 10 students in the Faculty of Psychology Universitas Indonesia to test their legibility. The results from the legibility test were reviewed by supervisors and experts, and items that were deemed confusing were modified to make them clearer. The research team then conducted trial runs of the IRMAS-SF, ASI and the 'Women Are Sexual Objects' subscale of the Attitude Toward Dating and Relationship Measure Revised on 63 students at Universitas Indonesia. Following legibility tests, reliability tests were conducted on SPSS software using Cronbach's alpha coefficient. The results of the reliability tests showed that there were two items (items 3 and 22 on the BS subscale) with consistent corrected item-total correlation scores below 0.2 . Item-total correlation values below 0.2 may indicate that the items are not discriminating well and should be eliminated. After reliability tests and the elimination of the two mentioned items, the reliability coefficient of the ASI was 0.824 , and the Cronbach's alpha coefficient of the BS subscale increased to 0.721 . Table 1 shows the results of the reliability tests for all instruments.

\section{Results}

The total number of respondents was 275 . Table 2 summarises the respondents' demographics. The descriptive analysis results showed that slightly less than half of the respondents were 17-20 years old and just over 51\% were 21-26 years old. The majority of the participants were Muslim, most were heterosexual, and approximately $63 \%$ were not in a romantic relationship.

Table 3 presents the results of the multiple regression analysis. The results of multiple regression analysis showed that ambivalent sexism and sexual objectification of women could predict rape myth acceptance in male college students. Ambivalent sexism and sexual objectification of women contributed $55.2 \%$ of the variance in rape myth acceptance $\left(\mathrm{R}^{2}=\right.$ $0.552, F(2,272)=167.629, p<0.05)$, whereas $44.8 \%$ of the variance could be explained by other variables. 
Table 1 Results of instrument reliability tests

\begin{tabular}{lllllll}
\hline Instrument & $\begin{array}{l}\text { Initial total } \\
\text { items }\end{array}$ & $\begin{array}{l}\text { Initial Cronbach's } \\
\text { alpha }\end{array}$ & $\begin{array}{l}\text { Initial corrected item } \\
\text { correlation }\end{array}$ & $\begin{array}{l}\text { Final total } \\
\text { items }\end{array}$ & $\begin{array}{l}\text { Final Cronbach's } \\
\text { alpha }\end{array}$ & $\begin{array}{l}\text { Final corrected item } \\
\text { correlation }\end{array}$ \\
\hline IRMAS-SF & 20 & 0.897 & $0.284-0.722$ & 20 & 0.897 & $0.284-0.722$ \\
ASI & 22 & 0.820 & $0.139-0.596$ & 20 & 0.824 & $0.254-0.604$ \\
Hostile Sexism & 11 & 0.836 & $0.333-0.667$ & 11 & 0.836 & $0.333-0.667$ \\
Benevolent Sexism & 11 & 0.694 & $0.044-0.602$ & 9 & 0.721 & $0.234-0.450$ \\
$\begin{array}{l}\text { Women Are Sexual } \\
\quad\end{array}$ & 8 & 0.644 & $-0.010-0.564$ & 7 & 0.703 & $0.206-0.408$ \\
\hline
\end{tabular}

Table 4 summarises the results of multiple regression analysis conducted to determine whether ambivalent sexism or sexual objectification of women was the greatest contribution to rape myth acceptance. The results showed that the contribution of sexual objectification of women $(\beta=0.419, t(2$, $271)=8.118, p<0.05)$ was greater than that of ambivalent sexism $(\beta=0.412, t(2,272)=8.255, p<0.05)$; however, the Fisher's $r$ test indicated only a negligible difference $(z=0.1)$ between the two variables.

Table 5 shows the results of multiple regression analysis conducted to determine the contributions of hostile and benevolent sexism and sexual objectification of women in predicting rape myth acceptance. Combined, these variables contributed $55.7 \%$ to rape myth acceptance variance $(F(3$, 271) $=113.405, p<0.05)$.

As shown in Table 6, the results showed that the contribution of $\operatorname{HS}(\beta=0.313, \mathrm{t}(2,271)=6.181, p<0.05)$ was greater than that of $\mathrm{BS}(\beta=0.144, \mathrm{t}(3,271)=2.688, p<0.05)$. The Fisher's $r$ test showed that the difference between HS and BS was significant ( $\mathrm{z}: 2.09$ ).

\section{Discussion}

The analysis revealed that ambivalent sexism and sexual objectification of women both significantly predicted rape myth acceptance among the participants. As much as $55.2 \%$ of the rape myth acceptance variance was predicted by ambivalent sexism and sexual objectification of women, and $44.8 \%$ of the variance was explained by other variables not measured in this study. These results align with those of previous studies demonstrating a relationship between ambivalent sexism and rape myth acceptance (Chapleau et al. 2007). Since ambivalent sexism has two dimensions, it can be concluded that there is a connection between rape myth acceptance with both hostile and benevolent sexism. Even so, additional analysis showed that the hostile sexism dimension had a greater contribution than benevolent sexism to predicting rape myth acceptance. This finding is in accordance with a previous study that found a closer relationship between hostile sexism and rape myth acceptance (Suarez and Gadalla 2010).
Table 2 Respondent demographics

\begin{tabular}{llll}
\hline Characteristic & & Number of Respondents & Percentage \\
\hline Age & $17-20$ years old & 134 & $48.7 \%$ \\
\multirow{3}{*}{ Religion } & $21-26$ years old & 141 & $51.3 \%$ \\
& Islam & 230 & $83.6 \%$ \\
& Christian, Protestant & 19 & $6.9 \%$ \\
& Catholic & 8 & $2.9 \%$ \\
& Buddhist & 11 & $4.0 \%$ \\
Sexual Orientation & Other & 2 & $0.7 \%$ \\
& Heterosexual & 5 & $1.8 \%$ \\
& Bisexual & 251 & $91.3 \%$ \\
Relationship Status & Homosexual & 14 & $5.1 \%$ \\
& Yes & 10 & $3.6 \%$ \\
& No & 103 & $37.5 \%$ \\
& & 172 & $62.5 \%$ \\
\hline
\end{tabular}


Table 3 Multiple regression to predict rape myth acceptance

\begin{tabular}{llllll}
\hline $\mathrm{R}$ & RSquare & Adjusted R Square & Std. Error of the Estimate & $\mathrm{F}$ & Sig. F \\
\hline 0.743 & 0.552 & 0.549 & 0.62 & 167.629 & $0.000^{* *}$ \\
\hline$* * p<0.05$ & & & & &
\end{tabular}

The results of the current study show that a majority of respondents exhibited ambivalent sexism at levels above the group mean. When ambivalent sexism scores were separated as a dimension, a large group of the respondents also had hostile and BS scores above the group mean. Within the BS dimension, the item 'women have to be loved and protected by men' from the protective paternalism component had the highest mean, thus indicating that many of the respondents agreed with the statement. Chapleau et al. (2007) explained that protective paternalism claims that men have more physical and culturally-based strength and authority compared to women and therefore does not support males who perpetrate sexual offences against women. This finding also explains the lesser contribution of BS than HS to rape myth acceptance.

The findings of this study also showed that the sexual objectification of women had a greater contribution than ambivalent sexism to predicting rape myth acceptance among respondents, although the difference between these variables was not significant. Sexual objectification contributed more than both hostile sexism and benevolent sexism to rape myth acceptance, and the difference between the contribution scores of sexual objectification and benevolent sexism is greater than that between the former variable and hostile sexism. This result could indicate that men with benevolently sexist attitudes indeed see women weaker and inferior; however, it is precisely because of this women should be protected rather than sexually objectified. Those who carry benevolent sexism views tend to oppose an indiscriminate legal process against sexual violence perpetrators and consider it necessary to consider the wishes of woman victims. This perception may be attributable to the idea that women's voices must be respected and that victims might experience further harm if the legal process is applied in a general manner. In short, views women as individuals who need to be respected and protected, albeit within a broader context of male superiority and patriarchy.

The above-discussed result could help explain why the sexual objectification of women predicted rape myth acceptance more than ambivalent sexism among this study's respondents. The contribution of sexual objectification to predicting rape myth acceptance is in accordance with the findings of Loughnan et al. (2013), which associated higher levels of objectification with perceptions that women who have experienced sexual violence bear responsibility for their victimisation.
The vast majority of male college students who participated in this study exhibited above average rape myth acceptance. This finding aligns with the results of previous studies (Johnson et al. 1997; Lonsway and Fitzgerald 1994; Suarez and Gadalla 2010; Szymanski et al. 1993). More specifically, the item 'rape happens when male sexual urges are out of control' under the 'He didn't mean to' subscale had the highest mean, thus indicating that the respondents tended to agree with the statement. This item implies a justification of rape that liberates or relieves a perpetrator from owning up to his actions. The results might have been different among females; however, such a comparison cannot be made in this study because it did not involve female respondents. According to Lonsway and Fitzgerald (1994), men tend to accept myths that justify rape due to sexual urges, whereas women tend to accept the myth that assumes only women with certain characteristics will be raped.

The sample in this study consisted of male undergraduate students from public or private universities in the Greater Jakarta region or Jabodetabek. With a population of over 26.7 million people in 2010 (Rustiadi et al. 2012), Jabodetabek is the largest metropolitan area in Indonesia. According to Kolko (2000), metropolitan areas are inhabited by a large number of internet users. Internet usage can expose individuals to much information that may not be accurate, including myths about rape. Furthermore, internet access makes it easier for people to view sexist content and/or messages that sexually objectifies women, which might influence rape myth acceptance, sexism and the sexual objectification of women among male college students in metropolitan areas.

This study has some limitations that should be considered when planning future research. The authors decided to limit the respondents to male college students because previous studies showed that men tended to have higher levels of rape myths acceptance and a greater tendency to conduct sexual offences. However, it seems better to include both men and women participants, as women also tend to endorse rape myths and it is necessary to examine similarities and differences between their views and those of men. This is important because public education is needed for both genders and must be adjusted or based on a proper understanding of the perceptions related to the prevalent myths. Another limitation is that this study is part of an umbrella project that incorporated other variables not discussed in this paper. Hence, the total number 
Table 4 Contributions of ambivalent sexism and sexual objectification of women to predicting rape myth acceptance

\begin{tabular}{lllllll}
\hline Model & \multicolumn{2}{l}{ Unstandardised Coefficient } & & Standardised Coefficients & $\mathrm{t}$ & Sig \\
\cline { 2 - 3 } & $\mathrm{B}$ & Std. Error & & Beta & & \\
\hline 1 (constant) & 0.286 & 0.174 & & & 1.643 & 0.101 \\
Ambivalent sexism & 0.498 & 0.481 & & 0.412 & 8.118 & $0.000^{*}$ \\
Sexual objectification & 0.427 & 0.030 & & 0.419 & 8.225 & $0.000^{*}$ \\
\hline
\end{tabular}

$* * p<0.05$

of items was relatively large and their completion might have been tedious and exhausting for participants.

This study included a critical review of the concept of and research on rape myths acceptance. Reece $(2013,2014)$ argued that the methodologies used in rape myth studies cannot differentiate between myths about rape and sexual scripts rooted in gender inequality and proposed that researchers focus on the more complex issue of sexual scripts. This suggestion indicates that research on rape myths acceptance could provide a more comprehensive understanding of the phenomenon if it is accompanied by qualitative data collection. Indepth or focused interviews would allow researchers to ask questions about the presence or absence of participants' views and behaviours that objectify women as well as the sexual scripts learned by men and women that direct their behaviour to facilitate or tolerate sexual violence. Sexual scripts might also be better able to explain the events and behaviours that occur in the aftermath of sexual violence incidents, thus further clarifying the relationship between sexism, the objectification of women and rape myth acceptance.

Gurnham $(2016, b)$ indicated the need for a more careful analysis by focusing on the language and metaphors used in debating rape myths, such as whether 'myths' are mistaken beliefs or rather comprise a more ideological way of thinking? Ellison and Munro (2010) conducted a mock jury study with a mini-rape trial reconstruction and proposed the possibility that jurors' reluctance to convict related to a more complex interplay of factors than to simple assumptions related to 'rape myth acceptance'. Their findings emphasise the need for mixed-methods or multiple approaches to obtain more comprehensive information as a means to better understand the problem of sexual violence. In fact, there have been many qualitative

Table 5 Multiple regression to predict rape myth acceptance based on sexism and sexual objectification

\begin{tabular}{llllll}
\hline $\mathrm{R}$ & RSquare & $\begin{array}{l}\text { Adjusted R } \\
\text { Square }\end{array}$ & $\begin{array}{l}\text { Std. Error of the } \\
\text { Estimate }\end{array}$ & $\mathrm{F}$ & Sig. F \\
\hline 0.746 & 0.557 & 0.552 & 0.62 & 113,405 & $0.000^{* *}$ \\
\hline
\end{tabular}

$* * p<0.05$ studies or reflections from the field that can be integrated with quantitative investigations to obtain a more complete understanding of this phenomenon and devise ways and strategies to implement prevention and intervention programmes.

\section{Conclusion}

Based on the analysis presented in this study, it can be concluded that ambivalent sexism and sexual objectification of women can significantly predict rape myth acceptance among the sample of male undergraduate students in the Greater Area of Jakarta, Indonesia. When ambivalent sexism was separated into the two dimensions of benevolent sexism and hostile sexism, the analysis showed that the latter had a greater contribution to predicting rape myth acceptance among male college students; however, sexual objectification of women had a relatively larger contribution than ambivalent sexism to predicting rape myth acceptance. The latter finding indicates that in order to develop and conduct prevention and treatment, both variables need to be addressed, with more attention given to the sexual objectification of women.

Table 6 Contributions of hostile sexism (HS), benevolent sexism (BS) and sexual objectification of women to rape myth acceptance

\begin{tabular}{|c|c|c|c|c|c|}
\hline \multirow[t]{2}{*}{ Model } & \multicolumn{2}{|c|}{$\begin{array}{l}\text { Unstandardised } \\
\text { Coefficient }\end{array}$} & \multirow{2}{*}{$\begin{array}{l}\text { Standardised } \\
\text { Coefficients } \\
\text { Beta }\end{array}$} & \multirow[t]{2}{*}{$\mathrm{t}$} & \multirow[t]{2}{*}{ Sig } \\
\hline & $\mathrm{B}$ & $\begin{array}{l}\text { Std. } \\
\text { Error }\end{array}$ & & & \\
\hline 1 (constant) & 0.268 & 0.174 & & 1.542 & 0.101 \\
\hline Hostile Sexism (HS) & 0.350 & 0.057 & 0.313 & 6.181 & $0.000 *$ \\
\hline $\begin{array}{l}\text { Benevolent Sexism } \\
\quad \text { (BS) }\end{array}$ & 0.146 & 0.054 & 0.144 & 2.688 & $0.008^{*}$ \\
\hline Sexual Objectification & 0.437 & 0.052 & 0.429 & 8.424 & $0.000 *$ \\
\hline
\end{tabular}

$* * \mathrm{p}<0.05$ 


\section{Recommendations}

Based on the study, the research team proposes some recommendations for future studies. In future studies, the sample should be expanded to include respondents with a greater variety of characteristics, such as female respondents and adults who are not college students. Norms should be created, mainly from the IRMAS-SF measure, to identify the group(s) with higher and lower degrees of rape myth acceptance, and this classification can help researchers determine which group requires more intervention.

Critical discussions indicate that the concept of rape myth acceptance also needs to be examined using a variety of methods, such as by integrating qualitative approaches in data collection and analysis, which would allow researchers to ask more elaborative questions and obtain information concerning more complex interplays of cultural norms, beliefs, behaviours and scripts related to sexual violence.

Acknowledgments The study was supported by a grant from Universitas Indonesia (Hibah Pitta 2017). On behalf of all authors, the corresponding author states that there is no conflict of interest.

\section{Compliance with Ethical Standards}

Informed Consent Informed consent was obtained from all individual participants included in the study.

Ethical Approval Ethical approval has been obtained from the Committee on Research Ethics at the Faculty of Psychology, University of Indonesia, who has decided that the study complies to the ethical standards in the discipline of psychology, Universitas Indonesia's Research Ethical Code of Conduct, and the Indonesian Psychology Association's Ethical Code of Conduct, under the letter No 277/ FPsi.Komite Etik/PDP.04.00/2018, signed by the chair of the Committee, Dr. Sri Redatin Retno Pudjiati, M.Si, Psikolog.

Open Access This article is distributed under the terms of the Creative Commons Attribution 4.0 International License (http:// creativecommons.org/licenses/by/4.0/), which permits unrestricted use, distribution, and reproduction in any medium, provided you give appropriate credit to the original author(s) and the source, provide a link to the Creative Commons license, and indicate if changes were made.

\section{References}

Allen, W. D. (2007). The reporting and underreporting of rape. Southern Economic Journal, 73(3), 623-641. https://doi.org/10.2307/ 20111915.

Aosved, A. C., \& Long, P. J. (2006). Co-occurrence of rape myth acceptance, sexism, racism, homophobia, ageism, classism, and religious intolerance. Sex Roles, 55(7-8), 481-492. https://doi.org/10.1007/ s11199-006-9101-4.

Barn, R., \& Kumari, V. (2015). Understanding complainant credibility in rape appeals: A case study of high court judgments and judges' perspectives in India. British Journal of Criminology, 55(3), 435453. https://doi.org/10.1093/bjc/azu112.

Barn, R., \& Powers, R. A. (2018). Rape myth acceptance in contemporary times: A comparative study of university students in India and the United Kingdom. Journal of Interpersonal Violence. https://doi. org/10.1177/0886260518775750.

Bartky, S. L. (1990). Femininity and domination: Studies in the phenomenology of oppression. New York: Routledge. https://doi.org/10. 4324/9780203825259.

Bohner, G., Jarvis, C., Eyssel, F., \& Siebler, F. (2005). The causal impact of rape myth acceptance on men's rape proclivity: Comparing sexually coercive and noncoercive men. European Journal of Psychology, 35(6), 819-828. https://doi.org/10.1002/ejsp.284.

Bohner, G., Eyssel, F., Pina, A., Siebler, F., \& Viki, G. T. (2009). Rape myth acceptance: Cognitive, affective and behavioural effects of beliefs that blame the victim and exonerate the perpetrator. In M. A. H. Horvath \& J. Brown (Eds.), Rape: Challenging contemporary thinking (pp. 17-45). Cullompton: Willan Publishing. https://doi. org/10.4324/9781843927129.

Brownmiller, S. (1975). Against our will: Men, women, and rape. New York: Bantam Books.

Burt, M. (1980). Cultural myths and supports for rape. Journal of Personality and Social Psychology, 38(2), 217-230. https://doi. org/10.1037/0022-3514.38.2.217.

Chapleau, K. M., Oswald, D. L., \& Russell, B. L. (2007). How ambivalent sexism toward women and men support rape myth acceptance. Sex Roles, 57(1-2), 131-136. https://doi.org/10.1007/s11199-0079196-2.

Commonwealth of Australia (2017). Challenging misconceptions about sexual offending: Creating an evidence-based resource for police and legal practitioners. Australian Institute of Family Studies and Victoria Police.

Ellison, L., \& Munro, V. (2010). Getting to (not) guilty: Examining jurors' deliberative processes in and beyond the context of a mock rape trial. Legal Studies, 30(1), 74-97. https://doi.org/10.1111/j. 1748-121X.2009.00141.x.

Erdem, A., \& Sahin, R. (2017). Undergraduates' attitudes toward dating violence: Its relationship with sexism and narcissism. International Journal of Higher Education, 6(6), 91-105. https://doi.org/10.5430/ ijhe.v6n6p91.

Estrich, S. (1976). Real rape: How the legal system victimises women who say no. London: Harvard University Press.

Fitzgerald, J. (2006). The attrition of sexual offenses from the New South Wales criminal justice system. Crime and Justice Bulletin No. 92. Sydney: NSW Bureau of Crime Statistics and Research.

Fonow, M. M., Richardson, L., \& Wemmerus, V. A. (1992). Feminist rape education: Does it work? Gender and Society, 6(1), 108-121. https://doi.org/10.1177/089124392006001007.

Fredrickson, B. L., \& Roberts, T. (1997). Objectification theory: Toward understanding women's lived experiences and mental health risks. Psychology of Women Quarterly, 21(2), 173-206. https://doi.org/10. 1111/j.1471-6402.1997.tb00108.x.

Frese, B., Moya, M., \& Megias, J. L. (2004). Social perception of rape: How rape myth acceptance modulates the influence of situational factors. Journal of Interpersonal Violence, 19(2), 143-161. https:// doi.org/10.1177/0886260503260245.

Gerger, H., Gerger, H., Kley, H., Bohner, G., \& Siebler, F. (2007). The acceptance of modern myths about sexual aggression (AMMSA) scale: Development and validation in German and English. Aggressive Behavior, 33, 422-440. https://doi.org/10.13072/midss. 440.

Glick, P., \& Fiske, S. T. (1996). The ambivalent sexism inventory: Differentiating hostile and benevolent sexism. Journal of Personality and Social Psychology, 70(3), 491-512. https://doi. org/10.1037/0022-3514.70.3.491.

Gurnham, D. (2016). Debating rape: To whom does the uncanny 'myth' metaphor belong? Journal of Law and Society, Special Issue: Law's Metaphors: Interrogating Languages of Law, Justice, and Legitimacy., 43(1), 123-143. https://doi.org/10.1111/j.1467-6478. 2016.00744.x. 
Gurnham, D. (2016b). A critique of carceral feminist arguments on rape myths and sexual scripts. New Criminal Law Review, 19(2), 141170. https://doi.org/10.1525/nclr.2016.19.2.141.

Johnson, B. E., Kuck, D. L., \& Schander, P. R. (1997). Rape myth acceptance and sociodemographic characteristics: A multidimensional analysis. Sex Roles, 36(11-12), 693-707. https://doi.org/10.1023/A: 1025671021697.

Kolko, J. (2000). The death of cities? The death of distance? Evidence from the geography of commercial internet usage. In I. Vogelsang \& B. M. Compaine (Eds.), The internet upheaval: Raising questions, seeking answers in communication policy. Cambridge: The MIT Press.

Komnas Perempuan (2015). Lembar fakta catatan tahunan (Catahu) 2014[Pages of facts yearly review 2014]. (2018, May 23), Retrieved from http://www.komnasperempuan.go.id/wp-content/ uploads/2015/03/Lembar-Fakta-Catatan-Tahunan-CATAHUKomnas-Perempuan-Tahun-2014.pdf.

Komnas Perempuan (2016). Lembar fakta catatan tahunan (Catahu) 2016 [Pages of facts yearly review 2016]. (2018, May 23), Retrieved from http:/www.komnasperempuan.go.id/wp-content/uploads/2016/03/ Lembar-Fakta-Catatan-Tahunan- CATAHU -Komnas-Perempuan2016.pdf.

Komnas Perempuan (2017). Lembar fakta catatan tahunan (Catahu) 2017 [Pages of facts yearly review 2017]. (2018, May 23), Retrieved from http://www.komnasperempuan.go.id/wp-content/uploads/2017/04/ CATAHU-2017-Komnas-Perempuan.pdf.

Komnas Perempuan (2018). Tergerusnya ruang aman perempuan dalam pusaran politik populisme. Catatan kekerasan terhadap perempuan Tahun 2017. [The erosion of women's safe spaces in the vortex of populism politics. Record of violence against women in 2017]. (2019, June 20), Retrieved from https:/www.komnasperempuan.go.id/file/ pdf file/2018/Publikasi/Catatan\%20Tahunan\%20Kekerasan\% 20Terhadap\%20Perempuan\%202018.pdf.

Krahe, B., Temkin, J., Bieneck, S., \& Berger, A. (2008). Prospective lawyers' rape stereotypes and schematic decision making about rape cases. Psychology, Crime \& Law, 14(5), 461-479. https://doi.org/ 10.1080/10683160801932380.

Lila, M., Gracia, E., \& García, F. (2013). Ambivalent sexism, empathy and law enforcement attitudes towards partner violence against women among male police officers. Psychology, Crime \& Law, 19(10), 907-919. https://doi.org/10.1080/1068316X.2012.719619.

Lonsway, K., \& Fitzgerald, L. (1994). Rape myths in review. Psychology of Women Quarterly, 18, 133-164. https://doi.org/10.1111/j.14716402.1994.tb00448.x.

Loughnan, S., Pina, A., Vasquez, E. A., \& Puvia, E. (2013). Sexual objectification increases rape victim blame and decreases perceived suffering. Psychology of Women Quarterly, 37(4), 455-461. https:// doi.org/10.1177/0361684313485718.

Malamuth, N. M. (1981). Rape proclivity among males. Journal of Social Issues, 37(4), 138-157. https://doi.org/10.1111/j.1540-4560.1981. tb01075.x.

Martinez, T., Wiersma-Mosley, J. D., Jozkowski, K. N., \& Becnel, J. (2018). "Good guys don't rape": Greek and non-Greek college student perpetrator rape myths. Behavioral Science, 8(7), 60. https:// doi.org/10.3390/bs8070060.

Nilsson, G. (2018). Rape in the news: On rape genres in Swedish news coverage. Feminist Media Studies, 1-17. https://doi.org/10.1080/ 14680777.2018.1513412.

Nussbaum, M. C. (1995). Objectification. Philosophy \& Public Affairs, 24(4), 249-291. https://doi.org/10.1111/j.1088-4963.1995.tb00032.

Page, A. D. (2008). Judging women and defining crime: Police officers' attitudes toward women and rape. Sociological Spectrum, 28(4), 389-411. https://doi.org/10.1080/02732170802053621.
Palermo, T., Bleck, J., \& Peterman, A. (2014). Tip of the iceberg: Reporting and gender-based violence in developing countries. American Journal of Epidemiology, 179(5), 602-612. https://doi. org/10.1093/aje/kwt295.

Payne, D., Lonsway, K., \& Fitzgerald, L. (1999). Rape myth acceptance: Exploration of its structure and its measurement using the Illinois rape myth acceptance scale. Journal of Research in Personality, 33(1), 27-68. https://doi.org/10.1006/jrpe.1998.2238.

Prochuk, A. (2018). We are here. Women's experiences of the barriers to reporting sexual assault. Vancouver: West Coast LEAF.

Ramos, M., Barreto, M., Ellemers, N., Moya, M., Ferreira, L. (2016) What hostile and benevolent sexism communicate about men's and women's warmth and competence. Group Processes \& Intergroup Relations, 21 (1):159-177. https://doi.org/10.1177/ 1368430216656921.

Reece, H. (2013). Rape myths: Is elite opinion right and popular opinion wrong? Oxford Journal of Legal Studies, 33(3), 445-473. https:// doi.org/10.1093/ojls/gqt006.

Reece, H. (2014). Debating rape myths. LSE Law, Society and Economy Working Papers, 21, 1-23.

Renzetti, C. M., Lynch, K., \& DeWall, C. N. (2015). Ambivalent sexism, alcohol use, and intimate partner violence perpetration. Journal of Interpersonal Violence, 33(2), 183-210. https://doi.org/10.1177/ 0886260515604412 .

Rustiadi, E., Pribadi, D. O., Pravitasari, A. E., Indraprahasta, G. S., \& Iman, L. S. (2012). Jabodetabek megacity: From city development toward urban complex management system. In R. B. Singh (Ed.), Urban development challenges, risks, and resilience in Asian mega cities (pp. 421-445). Tokyo: Springer Japan. https://doi.org/10. 1007/978-4-431-55043-3 22.

Smith, O., \& Skinner, T. (2017). How rape myths are used and challenged in rape and sexual assault trials. Social \& Legal Studies, 26(4), 441466. https://doi.org/10.1177/0964663916680130.

Stoltenberg, J. (2000). Refusing to be a man: Essay on sex and justice (Rev. ed.). London: UCL Press.

Suarez, E., \& Gadalla, T. M. (2010). Stop blaming the victim: A metaanalysis on rape myths. Journal of Interpersonal Violence, 25(11), 2010-2035. https://doi.org/10.1177/0886260509354503.

Syarif, H., \& Purnama, R. (2015) Lagi, karyawati diperkosa di angkot [Again, a female worker being raped in angkot], Sindonews. (2015, June 22), Retrieved from https://nasional.sindonews.com/read/ 1015319/149/lagi-karyawati-diperkosa-di-angkot-1434940425.

Szymanski, L. A., Devlin, A. S., Chrisler, J. C., \& Vyse, S. A. (1993). Gender roles and attitudes toward rape in male and female college students. Sex Roles, 29(1), 37-57. https://doi.org/10.1007/ BF00289995.

Ward, L. M. (2002). Does television exposure affect emerging adults' attitudes and assumptions about sexual relationships? Correlational and experimental confirmation. Journal of Youth and Adolescence, 31(1), 1-15. https://doi.org/10.1023/A:1014068031532.

Yolandasari, A. R. (2013). Perbandingan rape myth acceptance antara orang tua yang memiliki anak perempuan dewasa muda dengan penyidik unit pelayanan perempuan dan anak di Jakarta dan sekitarnya. [The comparison of rape myth acceptance between parents who have young adult female daughters and police investigators in the service unit for women and children] (Script of Bachelor Degree, unpublished). Depok: Faculty of Psychology, Universitas Indonesia.

Publisher's Note Springer Nature remains neutral with regard to jurisdictional claims in published maps and institutional affiliations. 